\title{
БИОХИМИЧЕСКИЕ АСПЕКТЫ ВЗАИМООТНОШЕНИЙ ГРИБОВ И РАСТЕНИЙ НА ПРИМЕРЕ ФУЗАРИОЗА ОВСА*
}

\author{
И.Г. ЛОСКУТОВ 1 , 2 , Т.В. ШЕЛЕНГА' ${ }^{1}$, А.В. КОНАРЕВ 1 , В.И. ХОРЕВА', \\ А.Л. ШАВАРДА ${ }^{2,}$, Е.В. БЛИНОВА', А.А. ГНУТИКОВ1
}

\begin{abstract}
Выяснение механизмов формирования устойчивости растений к грибным болезням (патогенным микроорганизмам) неизменно приводит к необходимости анализа биохимических факторов устойчивости. Фузариоз зерна (ФЗ) - грибное заболевание, поражающее зерновые злаки, в том числе пшеницу, ячмень и овес. В настоящей работе нами получены новые данные о влиянии фузариоза зерна на метаболомный профиль зерновок овса, связи показателей устойчивости с биохимическими признаками (содержание белка, масла, отдельных метаболитов), достоверные отличия устойчивых и неустойчивых к Ф3 форм овса. Целью работы было выявление характера связей между биохимическими показателями устойчивости сортов овса к поражению Fusarium culmorum и $\boldsymbol{F}$. sporotrichioides и накоплением микотоксинов, образуемых этими патогенами (соответственно дезоксиниваленол - ДОН и Т-2 токсин). Российские и зарубежные сорта, а также селекционные линии, относящиеся к пленчатым и голозерным формам овса (Avena sativa L.) (всего 24 образца), были получены из коллекции Всероссийского института генетических ресурсов растений им. Н.И. Вавилова (ВИР). Размножение семенного материала и выращивание образов для биохимических исследований проводили в полевых условиях (Пушкинский филиал ВИР, Ленинградская обл., 2015 год). Анализировали жирнокислотный состава масла (газожидкостная хроматография с масс-спектрометрией, хроматограф Agilent 6850, США), а также состав и содержание других метаболитов. Устойчивость растений изучали при искусственном заражении колосьев грибами $\boldsymbol{F}$. culmorum и $\boldsymbol{F}$. sporotrichioides (опытное поле Всероссийского НИИ защиты растений - ВИЗР, г. Санкт-Петербург-Пушкин, 2015 год). Содержание ДНК грибов Fusarium Link, продуцирующих трихотеценовые микотоксины, и микотоксинов определяли в размолотой пробе зерна: количество ДНК - методом ПЦР в реальном времени с использованием группоспецифичных праймеров на основе последовательности гена Tri5, количество Т-2 токсина и ДОН - методом твердофазного конкурентного иммуноферментного анализа. Достоверность различий биохимических показателей, включая метаболомные профили, между устойчивыми и неустойчивыми формами овса оценивали с использованием коэффициента Манна-Уитни при р $<0,05$. Были выявлены корреляционные связи между показателями устойчивости овса к фузариозу и биохимическими характеристиками. Показано, что высокобелковые формы овса поражаются фузариозом слабее и накапливают меньше токсинов, они более адаптивны к биотическому стрессу. Отмечена связь между устойчивостью к Ф3 и накоплением пипеколовой кислотой, моноацилглицеголов, тирозина, галактинола, ряда фитостеролов, сахаров и аденозина. Выявленные корреляции между продукцией химических соединений и различными показателями устойчивости образцов овса к фузариозу следует рассматривать как предварительные, поскольку получены результаты одного года полевых испытаний. Однако этот год характеризовался крайне благоприятными условиями для развития грибов Fusarium. Можно предположить, что их повышенная агрессивность позволила нам более надежно выявить связи между составом, содержанием метаболитов и показателями устойчивости растений к фузариозу. Для подтверждения (или опровержения) сделанных нами выводов, учитывая сложный полигенный характер контроля устойчивость к фузариозу зерна и сильную зависимость его проявления от окружающей среды, необходимо в дальнейшем исследовать большее внутри- и межвидовое разнообразие образцов, репродуцированных в разных условиях и в разные годы. Выявленные нами зависимости между показателями устойчивости и синтезом ряда метаболитами дадут возможность выделять устойчивые формы при скрининге коллекции ВИР и использовать их для последующих селекционных работ.
\end{abstract}

Ключевые слова: Avena sativa L., овес, сорта, фузариоз зерна, Fusarium, ДНК грибов, ПЦР, микотоксины, газовая хроматография, масс-спектрометрия, биохимия, метаболомика.

Фузариоз зерна (ФЗ) - грибное заболевание, поражающее зерновые злаки, в том числе пшеницу, ячмень и овес (1-3). Оно приводит к потерям урожая и рассматривается как глобальная угроза продовольственной безопасности (4). Наиболее распространенный вид, вызывающий Ф3, Fusarium graminearum Schwabe, продуцирующий дезоксиниваленол (ДОН). Этот микотоксин считается главным фактором агрессивности гриба, инги-

* Исследование поддержано проектом РНФ № 14-16-00072. 
бирующим, в частности, процессы трансляции у эукариот (5). Помимо экономического ущерба от снижения урожайности, микотоксины грибов рода Fusarium Link представляют угрозу здоровью населения, потребляющего такие продукты (4). Виды рода Fusarium выделяют токсины, обладающие различной агрессивностью. Так, F. culmorum (W.G. Sm.) Sacc. - высокоагрессивный патоген, продуцирующий ДОН, F. sporotrichioides Sherb. - относительно слабый патоген, образующий Т-2 токсин (6).

Аналитический подход, основанный на хроматографии в сочетании с масс-спектрометрией, позволяет контролировать изменения по многим метаболитам, в том числе тем, синтез которых индуцирован патогеном. Среди видов, вызывающих фузариоз овса, доминирует $F$. роае, продуцирующий микотоксин ниваленол. Предполагается, что этот токсин - основной фактор, который ухудшает питательные свойства овса. К сожалению, его контроль по ряду формальных причин не осуществляется (7-9).

Метаболомный подход к изучению грибных болезней позволяет обеспечить надежность идентификации компонентов и статистическую достоверность количественной оценки их изменчивости в системе растение-патоген (10). Устойчивость к фузариозу контролируется генами более чем сотни локусов количественных признаков и в значительной степени зависит от условий среды $(11,12)$. В процессе эволюции у растений выработались защитные реакции на воздействие патогенов. Растения-хозяева могут продуцировать химические соединения, ингибирующие развитие патогена, и обладают разнообразными стратегиями их применения, создавая защитные барьеры на всех этапах продвижения паразита (13).

К метаболическому ответу, индуцированному ДОН, относится потеря хлорофилла (14), поскольку на месте инфекции ослабевает фотосинтез (15). В результате модифицируются первичный (углеводный) и вторичный (азотный) метаболизм. Блокирование биосинтеза белков микотоксином приводит к накоплению свободных аминокислот (16).

Одно из приоритетных направлений метаболомики - изучение реакции организма на воздействие среды. Полученные профили (fingerprint) отражают метаболические состояния организма, в том числе в динамике развития ответной реакции (17).

В настоящей работе получены новые данные о влиянии фузариоза зерна на метаболомный профиль зерновок овса, связи показателей устойчивости с биохимическими признаками (содержание белка, масла, отдельных метаболитов), показаны достоверные отличия устойчивых (УФ) от неустойчивых (НФ) к ФЗ форм овса из коллекции Всероссийского института генетических ресурсов растений им. Н.И. Вавилова (ВИР).

Нашей целью было выявление характера связей между биохимическими показателями устойчивости сортов овса к поражению Fusarium culmorum и F. sporotrichioides и накоплением микотоксинов, образуемых этими патогенами (соответственно ДОН и Т-2 токсин).

Методика. Российские и зарубежные сорта, а также селекционные линии, относящиеся к пленчатым и голозерным формам овса (Avena sativa L.) (всего 24 образца), были получены из коллекции ВИР. Размножение семенного материала и выращивание образов для биохимических исследований проводили в полевых условиях (Пушкинский филиал ВИР, Ленинградская обл., 2015 год). Фенологические наблюдения и полевую оценку выполняли в соответствии с методическими указаниями (18), степень выраженности признаков определяли по Международному классификатору рода Avena L. (19). Посев семян осуществляли в оптимальный срок на де- 


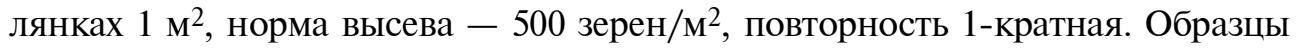
высевали в зерновом севообороте, предшественник - картофель. Почвы опытного поля - дерново-подзолистые легкосуглинистые.

Содержание белка и масла в семенах оценивали по принятым в ВИР методикам: белка - на приборах Kjeltec Auto 1030 Analyzer («FOSS», Швеция) и Kjeltec 2200 («FOSS», Швеция), масла - в аппарате Сокслета по массе сухого обезжиренного остатка (20). Жирнокислотный состав масла определяли методом газожидкостной хроматографии на хроматографе Agilent 6850 («Agilent», США) с квадрупольным масс-селективным детектором Agilent 5975B VL MSD («Agilent», США) (20). Стандартом для оценки образцов по основным хозяйственно ценным признакам служил сорт Привет, районированный в Ленинградской области.

Устойчивость растений изучали при искусственном заражении колосьев грибами F. culmorum и F. sporotrichioides (опытное поле Всероссийского НИИ защиты растений - ВИЗР, г. Санкт-Петербург-Пушкин, 2015 год). Каждый образец выращивали на делянках (длина ряда 1 м) в 2 повторностях для каждого инфекционного фона, делянки, разделенные массивом посева стандарта (овес сорта Borrus, контроль) располагались на одном участке поля. В фазу выметывания все образцы инокулировали суспензией конидий и мицелия грибов $F$. culmorum $\left(3 \times 10^{7}\right.$ KОЕ/мЛ) и F. sporotrichioides $\left(1,3 \times 10^{7} \mathrm{KOE} / \mathrm{Mл}\right)$, расход суспензий -50 мл/л.

После сбора и обмолота образцы оценивали по зараженности зерна, содержанию ДНК грибов и количеству микотоксинов в зерне. Зараженость определяли на стандартной картофельно-сахарозной агаризованной среде (КСА). Из каждого среднего образца отбирали 100 зерен, которые поверхностно стерилизовали $5 \%$ раствором гипохлорита натрия в течение 1-3 мин. Затем зерна отмывали стерильной водой и раскладывали в чашки Петри на КСА. Через 7 сут инкубирования в термостате (в темноте, при $24{ }^{\circ}$ ) ) подсчитывали численность фузариевых грибов. ДНК выделяли из 200 мг зерновой муки с помощью адаптированного СТАВ-метода (21-23). Типовые штаммы $F$. graminearum и $F$. poae из коллекции микроорганизмов лаборатории микологии и фитопатологии ВИЗР культивировали на картофельно-сахарозном агаре, после чего из воздушного мицелия грибов выделяли ДНК, используя набор реагентов Genomic DNA Purification Kit («Thermo Fisher Scientific», Литва). В размолотых пробах зерна определяли количество ДНК патогенов методом количественной ПЦР и содержание Т-2 токсина и ДОН методом иммуноферментного анализа (ИФА) по описанным ранее методикам (24).

На основании результатов оценки по устойчивости к Ф3 $(24,25)$ отобрали 10 образцов, для которых выполнили метаболомный анализ. Для этого зерно взвешивали и гомогенизировали с метанолом в соотношении 1/10 (масса/объем). Пробу настаивали в течение 30 сут при 5-6 ${ }^{\circ} \mathrm{C}$. Экстракт (100 мкл) выпаривали (CentriVap ${ }^{\circledR}$ Concentrator, «Labconco», США). Сухой остаток силилировали 40 мин при $100{ }^{\circ} \mathrm{C}$ с использованием бис(триметилсилил)трифторацетамида. Анализ проводили методом газожидкостной хроматографии с масс-спектрометрией (gas-liquid chromatography-mass-spectrometry, «Agilent», США) на капиллярной колонке HP-5MS («Agilent», США) с $5 \%$ фенилметилполисилоксаном (30,0 м, 250,00 мкм, 0,25 мкм) и Omegawax $^{\mathrm{TM} 250}$ fused silica capillary column $(30,0$ M, 250,00 MKM, 0,25 MKM, Supelсо®, «Sigma-Aldrich», США). Скорость потока гелия составляла 1,5 мл/мин. Начальная температура нагревания $-70^{\circ} \mathrm{C}$, конечная $-220^{\circ} \mathrm{C}$, скорость нагревания $-4{ }^{\circ} \mathrm{C} /$ мин. Температура детектора масс-спектрометра $-250{ }^{\circ} \mathrm{C}$, 
температура инжектора $-300{ }^{\circ} \mathrm{C}$, объем пробы -1 мкл. Внутренний стандарт - трикозан в пиридине (1 мкг/мкл). Полученные результаты обрабатывали с помощью программы UniChrom («Restek Corporation», США) (9).

Статистическую обработку результатов проводили с использованием программ Statistica 7.0 («StatSoft. Inc.», США) и Microsoft Excel 2010. Pacсчитывали средние значения $(M)$ и стандартные ошибки средних ( $\pm \mathrm{SEM})$. Достоверность различий между формами овса были установлены с помощью критериев Манна-Уитни и Тьюки. Различия считали статистически значимыми при $\mathrm{p} \leq 0,05$.

Результаты. Погодные условия в период вегетации (2015 год) были в основном благоприятными для роста и развития растений овса, а также для развития фузариозной инфекции.

Список изученных образцов представлен в таблице 1.

1. Образцы овса (Avena sativa L.) из коллекции Всероссийского института генетических ресурсов растений им. Н.И. Вавилова (ВИР), изученные по биохимическим хозяйственно ценным признакам и показателям устойчивости к фузариозному заражению (г. Санкт-Петербург-Пушкин, 2015 год)

\begin{tabular}{|c|c|c|c|}
\hline № по каталогу ВИР & Вид, разновидность & Сорт, линия & Происхождение \\
\hline K-14648 & A. sativa var. mutica & Аргамак & Кировская область \\
\hline K-11840 & A. sativa var. aurea & Borrus & Германия \\
\hline K-14960 & A. sativa var. inermis & Вятскийг & Кировская область \\
\hline K-15068 & A. sativa var. mutica & Конкур & Ульяновская область \\
\hline K-14851 & A. sativa var. inermis & Numbat ${ }^{\Gamma}$ & Австралия \\
\hline K-10841 & A. sativa var. aurea & Бисуандороду & Сахалинская область \\
\hline к-14329 & A. sativa var. aristata & Kouzan Zaizai & Япония \\
\hline K-13911 & A. sativa var. mutica & Камбулинский & Ленинградская область \\
\hline к-14911 & A. sativa var. mutica & Belinda & Швеция \\
\hline K-15297 & A. sativa var. aurea & Geszti & Венгрия \\
\hline K- 15305 & A. sativa var. chinensis & Gehl $^{\Gamma}$ & Канада \\
\hline K-15301 & A. sativa-A. byzantina & CDC Dancer & Канада \\
\hline K-15442 & A. sativa var. mutica & Залп & Московская область \\
\hline K-15496 & A. sativa var. mutica & Стиплер & Ульяновская область \\
\hline K-15444 & A. sativa var. mutica & Сапсан & Кировская область \\
\hline K-15494 & A. sativa-A. byzantina & Медведь & Кировская область \\
\hline K-15348 & A. sativa var. mutica & Hurdal & Норвегия \\
\hline K-15353 & A. sativa var. aurea & Odal & Норвегия \\
\hline K-15611 & A. sativa var. aurea & Bessin & Норвегия \\
\hline K-15612 & A. sativa var. aurea & Valer & Норвегия \\
\hline K-15347 & A. sativa var. mutica & Gere & Норвегия \\
\hline K-15326 & A. sativa var. mutica & КСИ 432/08 & Ульяновская область \\
\hline K-15327 & A. sativa var. mutica & КСИ 731/01 & Ульяновская область \\
\hline K-15506 & A. sativa var. mutica & Fux & Германия \\
\hline K- 14787 & A. sativa var. mutica & Привет & Московская область \\
\hline
\end{tabular}

Содержание ДНК грибов F. culmorum и F. sporotrichioides отражает степень поражения растений патогенами двух этих видов (26). Мы оценили устойчивость образцов к фузариозному заражению и накоплению микотоксинов по сочетанию трех показателей - зараженности зерна грибами, содержанию ДНК грибов и количеству их токсических метаболитов в зерне (табл. 2)

По результатам оценки образцы разделили на две группы - устойчивые (УФ) и неустойчивые (НФ), что было необходимо для дальнейшей оценки влияния факторов патогенности Ф3 на биохимические показатели, в том числе данные метаболомного анализа (табл. 3, 4). К устойчивым отнесли образцы овса, у которых количество ДНК $F$. culmorum и F. sporotrichioides в муке не превышало соответственно 0,22 и 0,29 пкг/г, а показатели по Т-2 токсину и ДОН были не выше 10 и 100 мкг/кг. Остальные образцы составили группу неустойчивых. Правильность формирования групп 
2. Характеристика образцов овса (Avena sativa L.) из коллекции Всероссийского института генетических ресурсов растений им. Н.И. Вавилова по показателям устойчивости к фузариозу $(n=3, M \pm \mathrm{SEM}$, г. Пушкин, 2015 год)

\begin{tabular}{|c|c|c|c|c|c|c|c|c|c|}
\hline \multirow{3}{*}{$\begin{array}{l}\text { № по каталогу } \\
\text { ВИР }\end{array}$} & \multirow{3}{*}{ Сорт, линия } & \multicolumn{4}{|c|}{ Fusarium sporotrichioides } & \multicolumn{4}{|c|}{ Fusarium culmorum } \\
\hline & & \multicolumn{2}{|c|}{ инфицированность } & \multicolumn{2}{|c|}{ продукция Т-2 токсина } & \multicolumn{2}{|c|}{ инфицированность } & \multicolumn{2}{|c|}{ продукция ДОН } \\
\hline & & $\begin{array}{l}\text { количество ДНК, } \\
\text { Пкг/г муки }\end{array}$ & $\begin{array}{l}\text { устойчивость } \\
\text { к заражению }\end{array}$ & $\begin{array}{l}\text { количество, } \\
\text { МКг/КГ }\end{array}$ & $\begin{array}{l}\text { устойчивость } \\
\text { К накоплению }\end{array}$ & $\begin{array}{l}\text { количество ДНК, } \\
\text { пкг/г муки }\end{array}$ & $\begin{array}{l}\text { устойчивость } \\
\text { к заражению }\end{array}$ & $\begin{array}{l}\text { количество, } \\
\text { МКг/Кг }\end{array}$ & $\begin{array}{l}\text { устойчивость } \\
\text { к накоплению }\end{array}$ \\
\hline K-14648 & Аргамак 1 & 0,08 & $\mathrm{y}$ & 0 & $\mathrm{y}$ & 0,13 & СУ & 213 & B \\
\hline $\mathrm{K}-11840$ & Borrus 1 & 0,11 & СУ & 14 & B & 0,15 & СУ & 64 & Су \\
\hline $\mathrm{K}-14960$ & Вятский ${ }^{11}$ & 0,06 & $\mathrm{y}$ & 5 & СУ & 0,15 & Су & 128 & B \\
\hline $\mathrm{K}-15068$ & Конкур & 0,31 & B & 7 & Су & 0,42 & B & 491 & $\mathrm{BB}$ \\
\hline $\mathrm{K}-14851$ & Numbat ${ }^{\mathrm{r} 1}$ & 0,13 & $\mathrm{CУ}$ & 59 & BB & 0,91 & BB & 285 & B \\
\hline $\mathrm{K}-10841$ & Бисуандороду & 0,04 & $\mathrm{y}$ & 5 & СУ & 0,05 & $\mathrm{y}$ & 131 & B \\
\hline $\mathrm{K}-14329$ & Kouzan Zaizai & 0,05 & $\mathrm{y}$ & 0 & $\mathrm{y}$ & 0,2 & Су & 148 & B \\
\hline $\mathrm{K}-13911$ & Камбулинский & 0,03 & $\mathrm{y}$ & 0 & $\mathrm{y}$ & 0,1 & Су & 45 & $\mathrm{y}$ \\
\hline $\mathrm{K}-14911$ & Belinda 1 & 0,25 & СУ & 60 & BB & 0,14 & Су & 456 & BB \\
\hline K-15297 & Geszti & 0,03 & $\mathrm{y}$ & 4 & СУ & 0,04 & $\mathrm{y}$ & 25 & $\mathrm{y}$ \\
\hline K-15305 & GehlГ1 & 0,05 & $\mathrm{y}$ & 23 & B & 0,03 & $\mathrm{y}$ & 20 & $\mathrm{y}$ \\
\hline $\mathrm{K}-15301$ & CDC Dancer & 1,29 & BB & 5 & Су & 0,1 & СУ & 41 & $\mathrm{y}$ \\
\hline K-15442 & Залп 1 & 0,63 & BB & 30 & B & 0,16 & СУ & 163 & B \\
\hline K-15496 & Стиплер & 0,10 & СУ & 0 & $\mathrm{y}$ & 0,03 & $\mathrm{y}$ & 33 & $\mathrm{y}$ \\
\hline K-15444 & Сапсан ${ }^{1}$ & 0,12 & СУ & 19 & B & 0,16 & СУ & 257 & B \\
\hline K-15494 & Медведь & 0,33 & B & 13 & B & 0,69 & BB & 72 & Су \\
\hline $\mathrm{K}-15348$ & Hurdal $^{1}$ & 0,85 & BB & 17 & B & 0,34 & B & 30 & $\mathrm{y}$ \\
\hline K-15353 & Odal & 0,34 & B & 7 & Су & 0,35 & B & 50 & $\mathrm{y}$ \\
\hline K-15611 & Bessin & 0,39 & B & 49 & B & 0,57 & BB & 331 & BB \\
\hline K-15612 & Veler & 0,29 & Су & 0 & $\mathrm{y}$ & 0,5 & $\mathrm{~B}$ & 77 & Су \\
\hline $\mathrm{K}-15347$ & Gere & 0,67 & BB & 133 & BB & 0,1 & СУ & 121 & B \\
\hline K-15326 & КСИ 432/08 & 0,86 & BB & 8 & Су & 3,64 & BB & 1179 & BB \\
\hline $\mathrm{K}-15327$ & КСИ 731/011 & 1,93 & BB & 45 & B & 0,22 & СУ & 97 & СУ \\
\hline K-15506 & Fux & 0,40 & B & 10 & Су & 0,09 & $\mathrm{y}$ & 331 & $\mathrm{BB}$ \\
\hline
\end{tabular}

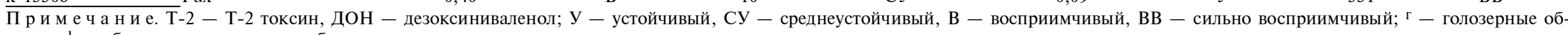
разцы, ${ }^{1}-$ образцы, взятые для метаболомного исследования. 
3. Характеристика образцов овса (Avena sativa L.) из коллекции Всероссийского института генетических ресурсов растений им. Н.И. Вавилова по биохимическим признакам качества $(n=3, M \pm \mathrm{SEM}$, г. Пушкин, 2015 год)

\begin{tabular}{|c|c|c|c|c|c|c|c|c|c|c|c|c|}
\hline \multirow[b]{2}{*}{$\begin{array}{l}\text { № по } \\
\text { каталогу ВИР }\end{array}$} & \multirow[b]{2}{*}{ Сорт, линия } & \multicolumn{2}{|c|}{ Содержание, \% } & \multicolumn{5}{|c|}{ Содержание жирных кислот, \% } & \multicolumn{2}{|c|}{ Сумма, \% } & \multicolumn{2}{|c|}{ Соотношение } \\
\hline & & белок, $\mathrm{N} \times 5,7$ & масло & $\mathrm{C}_{16: 0}$ & $\mathrm{C}_{18: 1}$ & $\mathrm{C} 1_{8: 2}$ & $\mathrm{C}_{18: 3}$ & $\mathrm{C}_{20: 1}$ & $\mathrm{HK}$ & HHK & $\begin{array}{l}\text { сумма ННК/ } \\
\text { сумма НК }\end{array}$ & 18:1/18:2 \\
\hline K-14648 & Аргамак ${ }^{1}$ & $11,5 \pm 0,02$ & $5,0 \pm 0,01$ & $19,3 \pm 0,02$ & $31,3 \pm 0,00$ & $44,4 \pm 0,03$ & $2,0 \pm 0,01$ & $0,5 \pm 0,01$ & $21,6 \pm 0,02$ & $78,4 \pm 0,01$ & 3,6 & 0,7 \\
\hline K-11840 & Borrus $^{1}$ & $12,8 \pm 0,01$ & $4,1 \pm 0,01$ & $20,0 \pm 0,02$ & $30,9 \pm 0,02$ & $45,0 \pm 0,01$ & $1,4 \pm 0,00$ & $0,5 \pm 0,00$ & $22,0 \pm 0,03$ & $78,0 \pm 0,02$ & 3,5 & 0,7 \\
\hline K-14960 & Вятский ${ }^{\Gamma 1}$ & $14,6 \pm 0,01$ & $6,5 \pm 0,00$ & $20,0 \pm 0,01$ & $40,6 \pm 0,03$ & $31,3 \pm 0,01$ & $3,5 \pm 0,01$ & $0,4 \pm 0,01$ & $24,1 \pm 0,02$ & $75,9 \pm 0,01$ & 3,1 & 1,3 \\
\hline K-15068 & Конкур & $12,7 \pm 0,01$ & $5,1 \pm 0,01$ & $20,9 \pm 0,02$ & $31,4 \pm 0,05$ & $43,0 \pm 0,01$ & $1,0 \pm 0,02$ & $0,6 \pm 0,02$ & $23,9 \pm 0,00$ & $76,1 \pm 0,02$ & 3,2 & 0,7 \\
\hline K-14851 & Numbat ${ }^{r 1}$ & $14,9 \pm 0,02$ & $7,9 \pm 0,00$ & $19,4 \pm 0,03$ & $34,3 \pm 0,01$ & $42,0 \pm 0,02$ & $1,3 \pm 0,01$ & $0,7 \pm 0,01$ & $21,6 \pm 0,02$ & $78,4 \pm 0,01$ & 3,6 & 0,8 \\
\hline K-10841 & Бисуандороду & $14,6 \pm 0,00$ & $3,9 \pm 0,01$ & $16,7 \pm 0,01$ & $38,8 \pm 0,02$ & $40,2 \pm 0,02$ & $1,2 \pm 0,01$ & $0,7 \pm 0,01$ & $19,1 \pm 0,03$ & $80,9 \pm 0,01$ & 4,2 & 1,0 \\
\hline K-14329 & Kouzan Zaizai & $13,5 \pm 0,00$ & $4,3 \pm 0,03$ & $18,1 \pm 0,00$ & $32,4 \pm 0,02$ & $44,6 \pm 0,02$ & $1,6 \pm 0,00$ & $0,8 \pm 0,02$ & $20,4 \pm 0,03$ & $79,6 \pm 0,01$ & 3,9 & 0,7 \\
\hline K-13911 & Камбулинский & $13,0 \pm 0,02$ & $3,8 \pm 0,01$ & $20,5 \pm 0,00$ & $29,5 \pm 0,02$ & $45,4 \pm 0,01$ & $1,7 \pm 0,03$ & $0,6 \pm 0,01$ & $22,7 \pm 0,01$ & $77,3 \pm 0,02$ & 3,4 & 0,7 \\
\hline K-14911 & Belinda ${ }^{1}$ & $11,6 \pm 0,00$ & $5,2 \pm 0,02$ & $19,0 \pm 0,02$ & $35,0 \pm 0,00$ & $41,2 \pm 0,01$ & $1,3 \pm 0,02$ & $0,6 \pm 0,00$ & $21,7 \pm 0,01$ & $78,3 \pm 0,01$ & 3,6 & 0,9 \\
\hline K-15297 & Geszti & $13,3 \pm 0,01$ & $5,8 \pm 0,02$ & $16,1 \pm 0,01$ & $44,4 \pm 0,03$ & $32,7 \pm 0,01$ & $2,4 \pm 0,04$ & $0,5 \pm 0,00$ & $19,9 \pm 0,03$ & $80,2 \pm 0,01$ & 4,0 & 1,4 \\
\hline K-15305 & Gehl ${ }^{\Gamma 1}$ & $15,5 \pm 0,01$ & $6,7 \pm 0,02$ & $16,8 \pm 0,01$ & $44,8 \pm 0,01$ & $34,8 \pm 0,01$ & $1,6 \pm 0,06$ & $1,0 \pm 0,02$ & $17,8 \pm 0,02$ & $82,2 \pm 0,01$ & 4,6 & 1,3 \\
\hline K-15301 & CDC Dancer & $10,3 \pm 0,01$ & $3,9 \pm 0,01$ & $17,6 \pm 0,01$ & $40,2 \pm 0,01$ & $38,4 \pm 0,01$ & $0,7 \pm 0,02$ & $0,7 \pm 0,01$ & $19,9 \pm 0,03$ & $80,1 \pm 0,02$ & 4,0 & 1,0 \\
\hline K-15442 & Залп ${ }^{1}$ & $11,7 \pm 0,01$ & $4,5 \pm 0,01$ & $16,6 \pm 0,01$ & $43,2 \pm 0,02$ & $36,6 \pm 0,01$ & $1,0 \pm 0,01$ & $0,6 \pm 0,01$ & $18,6 \pm 0,01$ & $81,4 \pm 0,01$ & 4,4 & 1,2 \\
\hline K-15496 & Стиплер & $11,5 \pm 0,01$ & $3,3 \pm 0,02$ & $17,7 \pm 0,02$ & $38,6 \pm 0,02$ & $38,4 \pm 0,02$ & $1,9 \pm 0,02$ & $0,8 \pm 0,01$ & $20,3 \pm 0,01$ & $79,7 \pm 0,00$ & 3,9 & 1,0 \\
\hline K-15444 & Сапсан ${ }^{1}$ & $12,5 \pm 0,00$ & $4,0 \pm 0,01$ & $16,5 \pm 0,02$ & $40,3 \pm 0,02$ & $39,1 \pm 0,02$ & $1,2 \pm 0,00$ & $0,7 \pm 0,02$ & $18,6 \pm 0,01$ & $81,4 \pm 0,02$ & 4,4 & 1,0 \\
\hline K-15494 & Медведь & $12,7 \pm 0,01$ & $4,5 \pm 0,01$ & $18,6 \pm 0,03$ & $39,1 \pm 0,02$ & $37,7 \pm 0,02$ & $1,4 \pm 0,01$ & $0,6 \pm 0,02$ & $21,2 \pm 0,01$ & $78,8 \pm 0,01$ & 3,7 & 1,0 \\
\hline K-15348 & Hurdal $^{1}$ & $11,8 \pm 0,01$ & $5,1 \pm 0,01$ & $19,1 \pm 0,02$ & $33,7 \pm 0,02$ & $42,6 \pm 0,01$ & $1,6 \pm 0,01$ & $0,6 \pm 0,03$ & $21,4 \pm 0,01$ & $78,6 \pm 0,01$ & 3,7 & 0,8 \\
\hline K-15353 & Odal & $12,2 \pm 0,01$ & $5,3 \pm 0,01$ & $18,1 \pm 0,02$ & $42,1 \pm 0,01$ & $35,5 \pm 0,01$ & $1,7 \pm 0,01$ & $1,0 \pm 0,01$ & $19,7 \pm 0,02$ & $80,3 \pm 0,01$ & 4,1 & 1,2 \\
\hline K-15611 & Bessin & $10,6 \pm 0,00$ & $4,1 \pm 0,02$ & $16,1 \pm 0,00$ & $44,0 \pm 0,02$ & $35,4 \pm 0,01$ & $2,0 \pm 0,01$ & $0,8 \pm 0,00$ & $17,8 \pm 0,01$ & $82,2 \pm 0,02$ & 4,6 & 1,2 \\
\hline K-15612 & Veler & $10,9 \pm 0,03$ & $5,3 \pm 0,01$ & $16,1 \pm 0,02$ & $45,0 \pm 0,02$ & $34,2 \pm 0,01$ & $2,4 \pm 0,01$ & $1,0 \pm 0,01$ & $17,4 \pm 0,01$ & $82,6 \pm 0,01$ & 4,7 & 1,3 \\
\hline K-15347 & Gere & $11,6 \pm 0,01$ & $5,6 \pm 0,03$ & $17,5 \pm 0,03$ & $36,4 \pm 0,01$ & $42,6 \pm 0,02$ & $1,5 \pm 0,01$ & $0,5 \pm 0,01$ & $19,0 \pm 0,00$ & $81,0 \pm 0,02$ & 4,3 & 0,9 \\
\hline K-15326 & КСИ 432/08 & $11,0 \pm 0,01$ & $4,6 \pm 0,02$ & $15,9 \pm 0,05$ & $43,4 \pm 0,01$ & $36,6 \pm 0,00$ & $1,0 \pm 0,01$ & $0,7 \pm 0,01$ & $18,2 \pm 0,00$ & $81,8 \pm 0,02$ & 4,5 & 1,2 \\
\hline K-15327 & КСИ 731/011 & $12,1 \pm 0,01$ & $5,0 \pm 0,01$ & $15,0 \pm 0,03$ & $42,5 \pm 0,01$ & $39,3 \pm 0,02$ & $0,5 \pm 0,02$ & $0,7 \pm 0,01$ & $16,9 \pm 0,01$ & $83,1 \pm 0,00$ & 4,9 & 1,1 \\
\hline K-15506 & Fux & $12,5 \pm 0,01$ & $3,0 \pm 0,01$ & $19,7 \pm 0,02$ & $42,8 \pm 0,02$ & $31,9 \pm 0,01$ & $0,4 \pm 0,02$ & $0,4 \pm 0,00$ & $24,5 \pm 0,00$ & $75,6 \pm 0,01$ & 3,1 & 1,3 \\
\hline
\end{tabular}

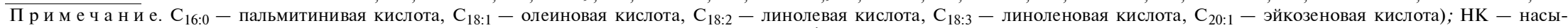
щенные жирные кислоты, ННК - ненасыщенные жирные кислоты; г - голозерные образцы, ${ }^{1}$ - образцы овса, взятые для метаболомного исследования. 
подтвердили с помощью критерия Тьюки для неравных выборок. Связь параметров устойчивости к Ф3 с данными исследования метаболома и другими биохимическими характеристиками зерна важно учитывать при селекции устойчивых сортов с высоким качеством (27). Показатели белка и масла в зерне у образцов овса в нашем исследовании составили в среднем соответственно 12,5 и 4,9\%, (см. табл. 3). Основной насыщенной жирной кислотой масла овса была пальмитиновая (до 20,9 \%), а ненасыщенными жирными кислотами (НHK) - олеиновая и линолевая (соответственно 38,5 и 38,9 \%). Сумма ННК оказалась довольно высокой для зерновых культур (до 83,1 \%), соотношение линолевой и олеиновой кислот было близко к единице. Такие показатели свидетельствуют о высоком пищевом качестве изученных образцов овса, что подтверждают ранее проведенные исследования (27).

С помощью неспецифического метаболомного анализа мы идентифицировали более 100 компонентов из групп органических кислот, свободных аминокислот (включая небелковые), многоатомных спиртов (в том числе фитостеролы), жирных кислот, нуклеозидов, моно- и олигосахаров, фенолсодержащих компонентов. Посредством парного сравнения результатов, полученных для УФ и НФ овса, с использованием коэффициента Мани-Уитни (при р < 0,05) были выявлены достоверные различия между УФ и НФ овса.

Согласно исследованием других авторов, грибные патогены влияют практически на все этапы первичного и вторичного метаболизма, что сказывается на изменении основных биохимических показателей, включая метаболомный профиль (28).

Нами отмечена обратная связь между содержанием белка у УФ овса и количеством ДНК $F$. sporotrichioides $(r=-0,5), F$. culmorum $(r=-0,6)$, а также токсина ДОН $(r=-0,5)$. У НФ была обнаружена только прямая связь с количеством ДНК $F$. sporotrichioides $(r=1)$. Содержание масла у УФ имело обратную связь с концентрацией токсинов Т-2 $(r=-0,6)$ и ДОН $(r=-0,6)$, у НФ - прямую с количеством ДНК $F$. sporotrichioides $(r=0,5)$ и ДНК $F$. culmorum $(r=0,5)$. Соотношения, полученные нами для УФ овса, позволяют предположить, что высокобелковые формы меньше поражаются и накапливают меньше токсинов. В то же время у НФ высокое содержание масла в зерновке способствовало развитию гриба. Наши предположения подтверждаются работами (29), в которых установлен характер влияния токсинов Ф3 на содержание белка и масла в зерновках злаковых.

Сообщалось (29), что Ф3 оказывает значительное воздействие на общее содержание свободных аминокислот. В нашем исследовании количество ДНК $F$. sporotrichioides у НФ овса прямо зависело от содержания свободных аминокислот $(r=0,5)$, что, скорее всего, связано с поражением рибосом и разрушением тканей растения при Ф3 (26). Между содержанием ДОН и общим количеством аминокислот у УФ овса установили обратную корреляцию $(r=-0,8)$, что может отражать активизацию механизмов защиты растения. Для НФ овса таких связей мы не обнаружили. Содержание ДОН у УФ имело прямую зависимость от концентрации аспарагина $(r=0,7)$ и глутамина $(r=0,6)$, у НФ - обратную (величина $r$ соответственно $-0,4$ и $-0,8$,$) . Кроме того, у УФ отмечалась обратная зависимость между$ содержанием ДНК $F$. sporotrichioides и количеством аспарагина $(r=-0,5)$, токсина Т-2 и глутамина $(r=-0,5)$. Повышение показателей по аспарагину и глутамину у УФ зерновых в ответ на поступление токсина в ткани 
растения подтверждено другими исследователями (26), которые связывают эти изменения с защитой растения от Ф3. Обсуждалось (29), что содержание пролина должно увеличиваться пропорционально концентрации токсинов, поскольку пролин участвует в инактивации свободных радикалов, которые накапливаются в растительных тканях при поражении ФЗ. Однако в нашем исследовании в группе НФ наблюдалась обратная связь между накоплением пролина и образованием токсина Т-2 $(r=-0,6)$.

Аминокислоты тирозин и фенилаланин - одни из составляющих шикиматного пути, продуктами которого становятся соединения, активно участвующие в защите растения, например фенилпропаноиды. По имеющимся данным (26), содержание тирозина, фенилаланина и вторичных метаболитов - продуктов шикиматного пути находится в прямой зависимости от показателей пораженности Ф3. Такая зависимость установлена нами для НФ между содержанием тирозина и ДНК $F$. sporotrichioides $(r=1)$, в остальных случаях между концентрацией тирозина и ДОН, а также фенилаланина и ДОН выявлены обратные связи (величина $r$ соответственно $-0,5$ и -0,7). Отрицательная корреляция между содержанием аланина и количеством ДНК и токсинами ФЗ как у УФ, так и у НФ овса подтверждается другими авторами (29). Данные эксприментов (16) свидетельствуют о повышении концентрации серина в ответ на воздействие токсинов Ф3, что не нашло подтверждения в нашем исследовании. Показатели по серину, наоборот, снижались, а коэффициенты корреляции между их значениями и продукцией токсинов Т-2 и ДОН составили соответственно $-0,6$ и $-0,5$.

Особого внимания при обсуждении полученных данных заслуживает пипеколовая кислота. Роль этой небелковой аминокислоты связывают с механизмами защиты растений от стрессовых факторов среды, в том числе от Ф3 $(26,29)$. Мы получили положительную корреляцию $(r=0,5)$ между содержанием этой кислоты и ДНК F. sporotrichioides и F. culmorum, а также ДОН у НФ; накопление ДОН у УФ овса находилось в обратной зависимости от содержания пипеколоой кислоты $(r=-0,8)$. Неодинаковое направление и разную силу этих корреляций можно объяснить различной степенью иммунной реакции у УФ и НФ овса.

У восприимчивых образцов мы установили отрицательную связь количества ДНК $F$. sporotrichioides с содержанием линоленовой кислоты (до $r=-0,7)$ и положительную - с показателем суммы ненасыщенных и насыщенных жирных кислот (величина $r$ соответственно до 0,7 и 0,7 ). Также была выявлена положительная зависимость между содержанием ДНК F. sporotrichioides и МАГ2-18:2 (моноацилглицерола) $(r=0,6)$, между ДНК F. culmorum и МАГ-2-18:2 $(r=0,6)$ и между ДНК F. culmorum и МАГ16:0 ( $r=0,5)$ (табл. 4). В предыдущей публикации (9) мы предположили, что моноацилглицеролы могут быть связаны с адаптивностью, в частности с устойчивостью к биотическим и абиотическим факторам среды, что нашло подтверждение у других исследователей (29). Содержание токсина ДОН положительно коррелировало с количеством линолевой $(r=0,6)$, эйкозановой $(r=0,5)$, эйкозеновой $(r=0,5)$ кислот и отрицательно - олеиновой $(r=-0,5)$ и линоленовой $(r=-0,5)$ кислот. Возможно, противоположные значения коэффициентов корреляций связаны с различной ролью тех или иных жирных кислот в жизнедеятельности гриба.

В группе образцов, устойчивых к Ф3, связь между концентрацией токсина ДОН и линоленовой кислотой усилилась до $r=-0,9$ по сравнению с восприимчивыми. Связь линоленовой кислоты с устойчивостью к 
Ф3 подтверждена (28). Между количеством Т-2 токсина и эйкозеновой кислоты прослеживалась отрицательная связь $(r=-0,5)$. Отрицательная корреляция между количествами ДНК $F$. sporotrichioides и линоленовой кислоты ослабевала до $r=-0,5$ по сравнению с показателем у восприимчивых образцов.

4. Характеристика устойчивых и неустойчивых к фузариозу форм овса (Avena sativa L.) из коллекции Всероссийского института генетических ресурсов растений им. Н.И. Вавилова по средним показателям накопления основных метаболитов $(n=25, M \pm \mathrm{SEM}$, г. Пушкин, 2015 год)

\begin{tabular}{|c|c|c|}
\hline \multirow{2}{*}{ Основные метаболиты, мг/100 г } & \multicolumn{2}{|c|}{ Формы овса } \\
\hline & устойчивые & неустойчивые \\
\hline Молочная кислота & $2,28 \pm 0,76$ & $1,89 \pm 0,51$ \\
\hline Метилмалоновая кислота & $2,85 \pm 0,82$ & $2,98 \pm 0,69$ \\
\hline Глицериновая кислота & $0,58 \pm 0,21$ & $0,61 \pm 0,18$ \\
\hline Эритроновая кислота & $0,828 \pm 0,31$ & $0,92 \pm 0,36$ \\
\hline Никотиновая кислота & $0,198 \pm 0,08$ & $0,20 \pm 0,10$ \\
\hline Глицин & $14,42 \pm 1,97$ & $12,67 \pm 2,33$ \\
\hline$\alpha$-Аланиин & $4,88 \pm 1,63$ & $5,16 \pm 1,80$ \\
\hline Валин & $1,95 \pm 0,77$ & $2,28 \pm 1,16$ \\
\hline Лейцин & $0,59 \pm 0,14$ & $0,61 \pm 0,14$ \\
\hline Пролин & $5,02 \pm 2,63$ & $4,87 \pm 2,65$ \\
\hline Серин & $2,42 \pm 1,12$ & $3,00 \pm 1,38$ \\
\hline Треонин & $1,64 \pm 0,95$ & $1,84 \pm 1,11$ \\
\hline Оксипролин & $0,80 \pm 0,63$ & $0,62 \pm 0,48$ \\
\hline Фенилаланин & $1,72 \pm 1,04$ & $1,66 \pm 0,81$ \\
\hline Тирозин & $32,51 \pm 17,58$ & $27,37 \pm 16,33$ \\
\hline Глутамин & $2,25 \pm 1,15$ & $2,12 \pm 1,06$ \\
\hline Аспарагин & $7,79 \pm 2,24$ & $9,62 \pm 3,82$ \\
\hline Сумма свободных аминокислот & $78,15 \pm 17,66$ & $74,01 \pm 16,52$ \\
\hline Этаноламин & $2,16 \pm 0,56$ & $2,17 \pm 0,67$ \\
\hline Пипеколовая кислота & $1,56 \pm 0,89$ & $1,78 \pm 1,13$ \\
\hline Аденозин & $3,22 \pm 0,75$ & $3,29 \pm 0,78$ \\
\hline МАГ-16:0 & $14,4 \pm 2,81$ & $14,23 \pm 2,69$ \\
\hline МАГ-2-18:2 & $31,75 \pm 6,73$ & $30,13 \pm 5,97$ \\
\hline Дульцитол & $18,38 \pm 3,72$ & $16,33 \pm 2,41$ \\
\hline Галактинол & $38,41 \pm 13,43$ & $36,87 \pm 11,5$ \\
\hline Хироинозитол & $0,37 \pm 0,12$ & $0,74 \pm 0,57$ \\
\hline Сумма многоатомных спиртов & $192,11 \pm 38,84$ & $188,17 \pm 24,61$ \\
\hline Холестерол & $0,64 \pm 0,19$ & $0,86 \pm 0,39$ \\
\hline Кампестерол & $0,69 \pm 0,23$ & $0,68 \pm 0,17$ \\
\hline Стигмастерол & $0,47 \pm 0,17$ & $0,55 \pm 0,20$ \\
\hline$\beta$-Ситостерол & $8,22 \pm 2,41$ & $9,51 \pm 2,41$ \\
\hline Сумма фитостеролов & $14,32 \pm 3,53$ & $17,95 \pm 5,24$ \\
\hline Глицероальдегид-3-фосфат & $10,72 \pm 3,85$ & $11,67 \pm 3,67$ \\
\hline Сумма моносахаров & $974,22 \pm 303,73$ & $843,34 \pm 175,47$ \\
\hline Сумма дисахаров & $2123,87 \pm 480,62$ & $2543,03 \pm 477,91$ \\
\hline
\end{tabular}

Мы не обнаружили связи между общим содержанием органических кислот и проявлениями устойчивости к Ф3, которую отмечали другие авторы. Между содержанием никотиновой кислоты и характеристиками Ф3 была установлена прямая связь (до $r=0,7$ ), а между содержанием эритроновой и метилмалоновой кислот - обратная (до $r=-0,9)$. Концентрация молочной кислоты положительно коррелировала с ДОН $(r=1)$ и Т-2 $(r=1)$ у УФ овса, и с ДНК $F$. sporotrichioides $(r=0,7)-$ у НФ. Отрицательная корреляция связывала накопление молочной кислоты и количество ДНК $F$. sporotrichioides $(r=-0,7)$ у УФ, а также ДНК $F$. culmorum $(r=-0,5)$ и ДОН $(r=-0,7)-$ у НФ овса. Изменения в содержании основных органических кислот первичного метаболизма, в том числе кислот цикла Кребса, под воздействием Ф3 подтверждают другие авторы $(26,29)$.

Суммарное содержание многоатомных спиртов было связано обратной корреляцией с количеством токсина ДОН: у НФ $r=-0,8$, у УФ $r=-0,5$. Содержание дульцитола у НФ коррелировало с накоплением токсинов ДОН и Т-2 (величина $r$ соответственно 0,6 и 0,7 ) и количеством 
ДНК F. culmorum $(r=0,7)$. В группе УФ была установлена обратная связь между показателями для галактинола и токсина ДОН, а также ДНК F. sporotrichioides $(r=-0,7)$. Обратная зависимость между концентрацией токсинов (ДОН, Т-2) и общим содержанием многоатомных спиртов подтверждена другими авторами (29), что вызвано влиянием Ф3 на первичный метаболизм. В то же время повышение содержания галактинола (28) связано с защитными механизмами растения при действии абиотических факторов среды, однако в этом случае изменение концентрации галактинола, очевидно, обусловлено влиянием Ф3.

Содержание фитостеролов, холестерола и $\beta$-ситостерола у НФ имело обратную связь с количеством ДНК $F$. sporotrichioides ( $r$ соответственно $-0,7 ;-0,7$ и $-0,5$,$) . В группе УФ мы также выявили обратную зависимость$ между содержанием ДОН и фитостеролов - кампестерола $(r=-0,6)$ и стигмастерола $(r=-0,6)$. Зависимость количества ДНК $F$. sporotrichioides от содержания $\beta$-ситостерола $(r=0,5)$ оказалась прямой в отличие от таковой у неустойчивых к Ф3 образцов. Установлено повышение количества эргостерола при фузариозном поражении листьев табака (29), так как фитостеролы участвуют в защите растений от биотических стрессов, что и подтверждают наши данные.

У НФ и УФ овса мы выявили обратную зависимость между показателями Ф3 (накопление ДНК F. sporotrichioides, ДНК F. culmorum, ДОН) и суммой моносахаров (до $r=-0,9$ ). Сумма дисахаров в группе УФ имела прямую зависимость от показателей ДОН $(r=0,9)$ и обратную - от количества ДНК F. sporotrichioides и содержания глицероальдегид-3-фосфата $(r=-0,5)$. В ряде исследований отмечается изменение содержания сахаров под влиянием возбудителей фузариоза. Обратная зависимость между показателями ДОН и содержанием сахаров может быть связана с инактивацией этого токсина с помощью синтеза конъюгированной с сахарами формы, а также увеличения активности гликолиза и пентозофосфатного цикла (26).

Корреляции между содержанием аденозина и ДНК F. sporotrichioides $(r=-0,5)$, а также ДОН $(r=-0,5)$ были выявлены только для группы НФ овса. Очевидно, что эта зависимость обусловлена влиянием гриба на синтез нуклеиновых кислот и белка в целом в пораженных тканях растения, сведений о выявлении подобных связей у других авторов нет.

Для всех полученных нами значений $r$ р $<0,05$.

Таким образом, Ф3 влияет практически на все этапы первичного метаболизма, в том числе на синтез белка, масла, сахаров, многоатомных спиртов, и активирует синтез соединений, связанных с защитой растения от гриба, к которым, в частности, относятся пипеколовые кислоты, ацилглицеролы, фитостеролы. Выявленная нами у УФ овса корреляция между содержанием белка и количеством ДНК основных возбудителей Ф3 дает основание полагать, что у высокобелковых форм степень поражения патогеном ниже и, как следствие, накапливается меныше токсинов, тогда как у НФ развитию инфекции способствует высокое содержание масла в зерновке. Отмеченная нами неодинаковая степень изменения содержания отдельных метаболитов и их групп может быть связана как с синтезом соединений, необходимых для жизнедеятельности гриба, так и с проявлением иммунных реакций со стороны тканей растения. Сопоставление данных по составу и содержанию в зерне важнейших химических групп соединений, в том числе минорных, с показателями устойчивости - необходимый этап при изучении биохимических процессов, происходящих при 
поражении растений патогенными микроорганизмами.

К физиолого-биохимическим факторам пассивного иммунитета относятся особенности обмена веществ, наличие и содержание в тканях растений химических соединений, выполняющих защитную роль, физикохимические особенности тканей и самих растений. Устойчивость, связанная с физиолого-биохимическими свойствами растений, может объясняться отсутствием в их тканях необходимых для возбудителя элементов питания, физиологически активных веществ, угнетением патогена токсичными соединениями или другими неблагоприятными для него факторами. В оптимальном случае растение может содержать вредные для патогенного гриба компоненты, например гликозиды - фенольные, цианогенные и другие соединения, а также синтезировать в ответ на микробную инфекцию фитоалексины $(13,30,31)$.

Метаболом растения (зерна) может быть в разной степени неблагоприятным для развития патогена, как было показано выше при анализе сортов овса с неодинаковой устойчивостью к фузариозу. Содержание соединений имеет разную степень и направленность связей с устойчивостью, характеризующуюся содержанием в зерне микотоксинов и ДНК грибов. Уместно вспомнить об адаптивной роли проламинов (авенинов) в формировании устойчивости злаков к биотическим и абиотическим факторам среды (32-34). Биохимический подход в сочетании с генетическим может обеспечить исследователей ценной информацией о механизмах защиты растений от фузариевых грибов (35). Нами отмечена связь между показателями устойчивости к ФЗ и накоплением в растении пипеколовой кислотой, моноацилглицеголов, тирозина, галактинола, ряда фитостеролов, сахаров и аденозина.

Итак, мы получили данные о связи широкого круга соединений с разными показателями устойчивости сортов овса к фузариозу, что важно не только для понимания природы этого признака, но и для разработки методов диагностики. Эти результаты одного года полевых испытаний следует рассматривать как предварительные, однако отметим, что 2015 год характеризовался крайне благоприятными условиями для развития грибов Fusarium. Можно предположить, что повышенная агрессивность последних позволила нам более надежно выявить зависимости состава и содержания метаболитов от показателей устойчивости растений к фузариозу. Учитывая сложный полигенный характер контроля устойчивости к фузариозу зерна и сильную зависимость проявления этого признака от условий окружающей среды, для подтверждения или опровержения сделанных нами выводов необходимо исследовать большее внутри- и межвидовое разнообразие образцов овса, репродуцированных в неодинаковых условиях и в разные годы. Тем не менее нам удалось выявить ряд зависимостей между показателями устойчивости и накоплением некоторых метаболитов, что дает возможность изначально отбирать образцы овса с высокими показателями по таким соединениям для селекции сортов овса, устойчивых к фузариозному заражению и обладающих высоким пищевым качеством. Продолжение этих исследований позволит нам расширить список компонентов метаболомного профиля, перспективных при отборе образцов овса на устойчивость не только к возбудителю фузариоза, но и к другим патогенам.

Авторы выражают искреннюю благодарность сотрудникам Всероссийского НИИ защиты растений (г. Санкт-Петербург-Пушкин) Т.Ю. Гагкаевой и О.П. Гавриловой за предоставление данных по устойчивости образиов овса к фузариозу зерна и 


\section{ЛИТЕРАТУРА}

1. Лоскутов И.Г. Овес (Avena L.). Распространение, систематика, эволюция и селекционная ценность. СПб, 2007.

2. Baum B.R. Oats: wild and cultivated. A monograph of the genus Avena L. (Poaceae). Monogr. No. 14. Ottava, Canada, 1977.

3. Гагкаева Т.Ю., Гаврилова О.П., Левитин М.М., Новожилов К.В. Фузариоз зерновых культур. Приложение к журналу «Защита и карантин растений», 2011, 5: 70-82.

4. Chakraborty S., Newton A.C. Climate change, plant diseases and food security: an overview. Plant Pathology, 2011, 60(1): 1-14 (doi: 10.1111/j.1365-3059.2010.02411.x).

5. Pestka J. Deoxynivalenol: mechanisms of action, human exposure, and toxicological relevance. Archives of Toxicology, 2010, 84(9): 663-679 (doi: 10.1007/s00204-010-0579-8).

6. Гагкаева Т.Ю., Гаврилова О.П., Левитин М.М. Биоразнообразие и ареалы основных токсинопродуцирующих грибов рода Fusarium. Биосфера, 2014, 6(1): 36-45.

7. Fiehn O., Kopka J., Dörmann P., Altmann T., Trethewey R.N., Willmitzer L. Metabolite profiling for plant functional genomics. Nature Biotechnology, 2000, 18(11): 1157-1161 (doi: 10.1038/81137).

8. Hill C. B., Roessner U. Metabolic profiling of plants by GC-MS. In: The handbook of plant metabolomics /W. Weckwerth, G. Kahl (eds.). Weinheim, Germany: Wiley-VCH Verlag GmbH \& Co. KGaA, 2013: 1-23.

9. Лоскутов И.Г., Шеленга Т.В., Конарев А.В., Шаварда А.Л., Блинова Е.В., Дзюбенко Н.И. Метаболомный подход к сравнительному анализу диких и культурных видов овса (Avena L.). Вавиловский журнал генетики и селекции, 2016, 20(5): 642-648 (doi: 10.18699/VJ16.185).

10. Choo T.M. Breeding barley for resistance to Fusarium head blight and mycotoxin accumulation. Plant Breeding Reviews, 2006, 26: 125-169 (doi: 10.1002/9780470650325.ch5).

11. Buerstmayr H., Ban T., Anderson J.A. QTL mapping and marker-assisted selection for Fusarium head blight resistance in wheat: a review. Plant Breeding, 2009, 128(1): 1-26 (doi: 10.1111/j.1439-0523.2008.01550.x).

12. Lemmens M., Scholz U., Berthiller F., Dall'Asta C., Koutnik A., Schuhmacher R., Adam G., Buerstmayr H., Mesterházy Á., Krska R., Ruckenbauer P. The ability to detoxify the mycotoxin deoxynivalenol colocalizes with a major quantitative trait locus for Fusarium head blight resistance in wheat. Molecular Plant-Microbe Interactions, 2005, 18(12): 1318-1324 (doi: 10.1094/MPMI-18-1318).

13. Дьяков Ю.Т., Тихонович И.А., Щербакова Л.А., Озерецковская О.Л., Джавахия В.Г., Проворов Н.А., Багирова С.Ф. Фундаментальная фитопатология /Под ред. Ю.Т. Дьякова. M., 2012.

14. Bushnell W.R., Perkins-Veazie P., Russo V.M., Collins J., Seeland T.M. Effects of deoxynivalenol on content of chloroplast pigments in barley leaf tissues. Phytopathology, 2009, 100(1), 3341 (doi: 10.1094/phyto-100-1-0033).

15. Bolton M.D. Current review: Primary metabolism and plant defense - fuel for the fire. Molecular Plant-Microbe Interactions, 2009, 22(5), 487-497 (doi: 10.1094/MPMI-22-5-0487).

16. Warth B., Parich A., Bueschl C., Schoefbeck D., Katharina N., Neumann N., Kluger B., Schuster K., Krska R., Adam G., Lemmens M., Schuhmacher R. GC-MS based targeted metabolic profiling identifies changes in the wheat metabolome following deoxynivalenol treatment. Metabolomics, 2015, 11(3): 722-738 (doi: 10.1007/s11306-014-0731-1).

17. Ситкин С.И., Ткаченко Е.И., Вахитов Т.Я., Орешко Л.С., Жигалова Т.Н. Метаболом сыворотки крови по данным газовой хроматографии-масс-спектрометрии (rX-MC) у пациентов с язвенным колитом и больных целиакией. Экспериментальная гастроэнтороскопия, 2013, 12: 77-90.

18. Лоскутов И.Г., Ковалева О.Н., Блинова Е.В. Методические указания по изучению и сохранению мировой коллекции ячменя и овса. СПб, 2012.

19. Oat Descriptors. IBPGR, Rome, 1985.

20. Методы биохимического исследования растений /Под ред. А.И. Ермакова. Л., 1987.

21. Halstensen A.S., Nordby K.C., Eduard W., Klemsdal S.S. Real-time PCR detection of toxigenic Fusarium in airborne and settled grain dust and associations with trichothecene mycotoxins. Journal of Environmental Monitoring, 2006, 8(12): 1235-1241 (doi: 10.1039/b609840a).

22. Yli-Mattila T., Paavanen-Huhtala S., Jestoi M., Parikka P., Hietaniemi V., Gagkaeva T., Sarlin T., Haikara A., Laaksonen S., Rizzo A. Real-time PCR detection and quantification of Fusarium poae, F. graminearum, F. sporotrichioides and F. langsethiae in cereal grains in Finland and Russia. Archives of Phytopathology and Plant Protection, 2008, 41(4): 243-260 (doi: 10.1080/03235400600680659). 
23. European commission. Community reference laboratory for GM food and feed. Event-specific for the quantitation of maize line NK603 using real-time PCR. 2005. Режим доступа: http://gmocrl.jrc.ec.europa.eu/summaries/NK603report_mm.pdf. Без даты.

24. Gagkaeva T.Yu., Gavrilova O.P., Orina A.S., Blinova E.V., Loskutov I.G. Diversity of Avena species by morphological traits and resistance to Fusarium head blight. Russian Journal of Genetics: Applied Research, 2018, 8(1): 44-51 (doi: 10.1134/S2079059718010070).

25. Perkowski J., Stuper K., Busko M., Goral T., Kaczmarek A., Jelen H. Differences in metabolomic profiles of the naturals contaminated grain of barley, oats and rye. Journal of Cereal Science, 2012, 56: 544-551 (doi: 10.1016/j.jcs.2012.07.012).

26. Nussbaumer T., Warth B., Sharma S., Ametz C., Bueschl C., Parich A., Pfeifer M., Siegwart G., Steiner B., Lemmens M., Schuhmacher R., Buerstmayr H., Mayer K.F.X., Kugler K.G., Schweiger W. Joint transcriptomic and metabolomic analyses reveal changes in the primary metabolism and imbalances in the subgenome orchestration in the bread wheat molecular response to Fusarium graminearum. Genes, Genomes, Genetics, 2015, 5(12): 2579-2592 (doi: $10.1534 / \mathrm{g} 3.115 .021550)$.

27. Конарев А.В., Шеленга Т.В., Перчук И.Н., Блинова Е.В., Лоскутов И.Г. Характеристика разнообразия овса (Avena L.) из коллекции ВИР - исходного материала для селекции на устойчивость к фузариозу. Аграрная Россия, 2015, 5: 2-10.

28. Balmer D., Flors V., Glauser G., Mauch-Mani B. Metabolomics of cereals under biotic stress: current knowledge and techniques. Front. Plant Sci., 2013, 4(82): 1-12 (doi: 10.3389/fpls.2013.00082).

29. Heuberger A.L., Robison F.M., Lyons S.M.A., Broeckling C.D., Prenni J.E. Evaluating plant immunity using mass spectrometry-based metabolomics workflows. Front. Plant Sci., 2014, 5(291): 1-11 (doi: 10.3389/fpls.2014.00291).

30. Hollywood K., Brison D.R., Goodacre R. Metabolomics: current technologies and future trends. Proteomics, 2006, 6(17): 4716-4723 (doi: 10.1002/pmic.200600106).

31. Zilić S., Hadzi-Tasković Sukalović V., Dodig D., Maksimović V., Maksimovié M., Basić Z. Antioxidant activity of small grain cereals caused by phenolics and lipid soluble antioxidants. Journal of Cereal Science, 2011, 54(3): 417-424 (doi: 10.1016/j.jcs.2011.08.006).

32. Семихов В.Ф., Арефьева Л.П., Новожилова О.А. Адаптированные типы проламинов специализированных белков семян злаков. Физиология растений, 2000, 3: 303-321.

33. Allard R.W. Genetic basis of the evolution of adaptedness in plants. In: Adaptation in plant breeding /P.M.A. Tigerstedt (ed.). Kluwer Academic Publishers, 1996: 1-11.

34. Schauer N., Fernie A.R. Plant metabolomics: towards biological functions and mechanism. Trends Plant Sci., 2006, 11(10): 508-516 (doi: 10.1016/j.tplants.2006.08.007).

35. Kluger B., Bueschl C., Lemmens M., Michlmayr H., Malachova A., Koutnik A., Maloku I., Berthiller F., Adam G., Krska R., Schuhmacher R. Biotransformation of the mycotoxin deoxynivalenol in Fusarium resistant and susceptible near isogenic wheat lines. PLoS ONE, 2015, 10(3): e0119656 (doi: 10.1371/journal.pone.0119656).

\section{${ }^{1}$ ФГБНУ ФИЦ Всероссийский институт} генетических ресурсов растений им. Н.И. Вавилова, 190000 Россия, г. Санкт-Петербург, ул. Большая Морская, 42-44, e-mail: i.loskutov@vir.nw.ru $₫$, t.shelenga@vir.nw.ru, a.konarev@vir.nw.ru, e.blinova@vir.nw.ru, alexandr2911@yandex.ru;

2ФГБОУ ВО Санкт-Петербургский государственный аграрный университет, 196601 Россия, г. Санкт-Петербург-Пушкин, Петербургское ш., 2; зФГБУН Ботанический институт им. В.Л. Комарова РАН, 197376 Россия, г. Санкт-Петербург, ул. Профессора Попова, 2, e-mail: stachyopsis@gmail.com
Поступила в редакцию 20 сентября 2018 года

Sel'skokhozyaistvennaya biologiya [Agricultural Biology], 2019, V. 54, № 3, pp. 575-588

\title{
BIOCHEMICAL ASPECTS OF INTERACTIONS BETWEEN FUNGI AND PLANTS: A CASE STUDY OF FUSARIUM IN OATS
}

\author{
I.G. Loskutov', 2, T.V. Shelengal, A.V. Konarev' ${ }^{1}$, V.I. Horeva ${ }^{1}$, A.L. Shavarda', 3 , \\ E.V. Blinova ${ }^{1}$, A.A. Gnutikov' ${ }^{1}$
}

${ }^{1}$ Federal Research Center Vavilov All-Russian Institute of Plant Genetic Resources, 42-44, ul. Bol'shaya Morskaya, St. Petersburg, 190000 Russia, e-mail i.loskutov@vir.nw.ru ( $₫$ corresponding author), t.shelenga@vir.nw.ru, a.konarev@vir.nw.ru, horeva43@mail.ru, e.blinova@vir.nw.ru, alexandr2911@yandex.ru;

${ }^{2}$ Saint-Petersburg State Agrarian University, 2, Peterburgskoe sh., St. Petersburg-Pushkin, 196601 Russia;

${ }^{3}$ Komarov Botanical Institute RAS, 2, ul. Professora Popova, St. Petersburg, 197376 Russia, e-mail: stachyopsis@gmail.com 
Loskutov I.G. orcid.org/0000-0002-9250-7225

Shelenga T.V. orcid.org/0000-0003-3992-5353

Konarev A.V. orcid.org/0000-0003-2938-1014

Horeva V.I. orcid.org/0000-0003-2762-2777

The authors declare no conflict of interests

Acknowledgements:

The authors express their sincere gratitude to T.Yu. Gagkayeva and O.P. Gavrilova (All-Russian Research Institute of Plant Protection, St. Petersburg) for providing data on plant resistance to Fusarium and mycotoxin accumulation in grain.

Supported financially by Russian Science Foundation, project No. 14-16-00072

Received September 20, 2018

doi: 10.15389 /agrobiology.2019.3.575eng
Shavarda A.L. orcid.org/0000-0003-1778-2814

Blinova E.V. orcid.org/0000-0002-8898-4926

Gnutikov A.A. orcid.org/0000-0002-5264-5594

\section{Abstract}

Disclosing the mechanisms that build up plant resistance to fungal diseases (pathogenic microorganisms) invariably evokes the need to analyze biochemical factors of resistance. Protective mechanisms are associated with a fairly large number of chemical compounds. Fusarium head blight (FHB) affects cereal grains, including wheat, barley and oats. In this work, we report new data on the metabolic profile of oat grains, as influenced by FHB, and a relationship between plant resistance and content of individual metabolites in FHB-susceptible and FHB-resistant varieties. Here, we have challenged the task to assess the connections of FHB-resistance parameters in oat varieties with as many compounds as possible. Such data are required both to understand the mechanisms of resistance and to develop methods for its assessment. Common oat (Avena sativa L.) varieties from the collection of the Vavilov Institute (VIR) were studied to evaluate their numerous biochemical characters and their resistance to FHB. The fatty acid composition of oil was analyzed by the method of gas-liquid chromatography with mass spectrometry on an Agilent 6850 chromatographer (USA), and other metabolites were quantitated. Plant resistance was studied under artificial infestation of ears with F. culmorum and F. sporotrichioides (an experimental field, All-Russian Research Institute for Plant Protection, St. Petersburg-Pushkin, 2015). Fusarium Link fungi DNA content and trichothecene mycotoxins were determined in milled grain samples. The amount of DNA of Fusarium fungi was measured by real-time PCR techniques using Tri5 gene-based group-specific primers. Solidphase competitive enzyme-linked immunosorbent assay (ELISA) was used to measure the content of T-2 toxin and DON in grain. The statistical significance of differences in biochemical parameters, including metabolic profiles, between resistant and susceptible oat varieties was estimated with the Mann-Whitney criterion. For the first time, correlations were found between Fusarium resistance and biochemical characteristics of oat. It has been shown that high-protein forms are less affected by FHB, accumulate less toxins, and are more adaptive to biotic stress. Plant resistance to FHB correlates with accumulation of pipecolic acid, monoacylglycegols, tyrosine, galactinol, a number of phytosterols, sugars and adenosine. The values of such correlations and connections between chemical compounds and various parameters of Fusarium resistance identified during the study of oat accessions should be regarded as strictly preliminary, since they are the outcome of only one year of field trials. However, the year in consideration was characterized by extremely favorable conditions for the development of parasitic Fusarium fungi with all immanent consequences. An assumption can be made that the increased aggressiveness of the latter (kind of a model condition) allowed us to identify with more reliability the connections between a majority of metabolite content and composition parameters and the level of Fusarium resistance. Considering the complex polygenic nature of the control over the character "resistance to Fusarium head blight" and, therefore, strong dependence of its expression on the environments, any future efforts to confirm (or refute) our conclusions will require researching greater intra- and interspecies diversity of this crop's accessions reproduced in various environments and in different years.

Keywords: Avena sativa L., oat, varieties, Fusarium head blight, Fusarium, fungal DNA, PCR, mycotoxins, gas chromatography, mass spectrometry, biochemistry, metabolomics.

\section{Научные собрания \\ 4-й МЕЖДУНАРОДНЫЙ СЕЛЬСКОХОЗЯЙСТВЕННЫЙ ФОРУМ «ЗЕРНО РОССИИ 2020»}

(14 февраля 2020 года, г. Краснодар)

\section{Основные темы форума:}

- Обзор российского зернового рынка, прогнозы производства и динамики цен, экспорт зерна и продуктов его переработки

- Новые технологии для выращивания и уборки зерновых

- Качество зерна, технологии улучшения и повышения урожайности, уборка и хранение

Контакты и информация: http://events.agbz.ru/

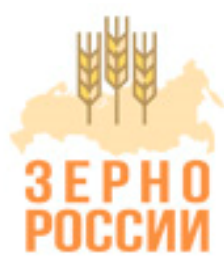

